\title{
Correction
}

\section{Correction: High Rates of Gene Flow by Pollen and Seed in Oak Populations across Europe}

\section{The PLOS ONE Staff}

Reference 69 is incorrect. The correct reference is: Leonarduzzi C, Leonardi S, Menozzi P, Piotti A (2012) Towards an optimal sampling effort for paternity analysis in forest trees: what do the raw numbers tell us? iForest, 5: 18-25. DOI: 10.3832/ifor0606009

\section{Reference}

1. Gerber S, Chadœuf J, Gugerli F, Lascoux M, Buiteveld J, et al. (2014) High Rates of Gene Flow by Pollen and Seed in Oak Populations across Europe. PLoS ONE 9(1): e85130. doi:10.1371/journal.pone.0085130
Citation: The PLOS ONE Staff (2014) Correction: High Rates of Gene Flow by Pollen and Seed in Oak Populations across Europe. PLoS ONE 9(2): e91301. doi:10. 1371/journal.pone.0091301

Published February 28, 2014

Copyright: () 2014 The PLOS ONE Staff. This is an open-access article distributed under the terms of the Creative Commons Attribution License, which permits unrestricted use, distribution, and reproduction in any medium, provided the original author and source are credited. 